\title{
Key Day Analysis on the Relationship between Solar Activity and Precipitation
}

\author{
By K. Takahashi \\ Meteorological Research Institute, Tokyo \\ (Manuscript received 23 June 1966)
}

\begin{abstract}
Relationship between solar activity and precipitation was studied by means of key day analysis. Daily amounts of precipitation are averaged at several stations in the Far East during the period of intense solar flare and strong and weak geomagnetic disturbance. Distinct increase of precipitation is found on days with intense solar flare. This suggests that soft $\mathrm{X}$ ray or very fast particle flow (probably cosmic rays emmitted from solar flare) stimulates the precipitation. Increases of precipitation are also found at some stations on days with strong geomagnetic disturbance or 6 days later. This may be due to secondary circulations which are stimulated by the initial responses.
\end{abstract}

\section{Introduction}

Response of weather phenomena to the changes of solar activity is an interesting but difficult problem. Ten years ago a seminar on this problem was held at the High Altitude Observatory at Boulder, Colorado (Roberts, 1956). The importance of corpuscular emission from the sun to the earth's atmosphere was emphasized at the meeting. A good deal of research has already been made on this topic. For instance, Duell and Duell (1948), Craig (1952), Shapiro (1956), Woodbridge (1957), Trenkle (1957), Asakura and Katayama (1958) and others have made key day analysis between meteorological elements and geomagnetic disturbances, which is occurred by an invasion of solar corpuscular flow into the upper atmosphere. They have found statistically significant change of meteorological elements several days after geomagnetically disturbed days. Of course, the changes of the meteorological elements, which are mostly surface pressure, height of a constant pressure, zonal index and trough due to changes of solar activity, are small. These relationships are observed only statistically by using large samples.

These changes, however, will express the indirect effects of the solar corpuscular flow. This probably takes place through the general circulation, because if the changes were direct ones, they would have to occur on the same geomagnetically disturbed day.

Sekihara (1963) has performed similar research on the relationships between solar flare index, geomagnetic disturbances and total zone amount. He found that the ozone decreases on geomagnetically disturbed days over the aurora zone and one or two days before over low latitude areas. $\mathrm{He}$ found, however, no appreciable change of ozone associated with the solar flare index. $\mathrm{He}$ suggested that the soft $X$ ray in the solar radiation will affect the ozone content on the earth.

Though no definite conclusions have been made as to what kind of solar radiation is most significant, these researchers have shown that the influence of solar activity upon the weather from solar flares is statistically significant. Since the beginning of the I.G.Y. we have excellent observations of solar flare activity. Few studies have been made on the relationship between the weather and the direct index of solar flare. We know that the change of solar activity is energetically quite small, hence, a physical explanation on the relationship between solar activity and weather responses is quite difficult.

The importance of condensation nuclei or ice nuclei for the formation of rain is well 
known. An interdisciplinary symposium on possible meteoric or lunar influences on meteorological phenomena was held in 1964 at Montreal, Quebec (Roberts, 1965). At the meeting it was suggested that the supply of active freezing nuclei with important meteorological consequence in the lower atmosphere is received from space or from some abandunt source at heights above $25 \mathrm{~km}$. If so, the corpuscular flow, soft $\mathrm{X}$ ray or cosmic ray may alter the number and/or effectiveness of ice or condensation nuclei and change the consequent precipitation. The first step to confirm this hypothesis is to make a statistical analysis of the corpusclar flow, solar flare and the precipitation amounts.

Accordingly, key day analysis of the geomagnetic disturbances as well as solar flare and daily amounts of precipitation was made. Statistically significant changes were found. As a result, this will add to our information on the relationship between the solar activity and the weather although the relationship is not a direct one.

\section{Key day analysis}

The method of key day analysis will be explained briefly. Let us define the key day as a day on which intense solar flares occur. On the selected key days, the day before, and the day after, daily precipitation amounts are collected at certain stations. The mean precipitation and percentage of days with precipitation are calculated. If there is no relationship between the precipitation and solar flare, the calculated mean values must be statistically equal and independent on time length from the key day. If there are statistically significant differences between these averaged values, there must be a correlation between solar flares and precipitation. We may be able to infer a mechanism concerning a possible solar weather relationship.

Here the statistical significance is judged by comparing the difference between calculated mean precipitation and expected precipitation. If the difference is larger than two or three times the standared deviation, (which is calculated assuming no statistical relationship between daily precipitations) then this difference is significant with a risk of but $2.3 \%$ and $0.13 \%$ respectively. In this deter- mination the expected standard deviation is estimated by the following formula,

Standard deviation of the averaged precipitation $\varepsilon=\sigma_{p} / \sqrt{N}$

Standard deviation of the averaged percentage of days with precipitation

$$
\gamma=\sqrt{p(1-p)} / N
$$

where $N$ is sample size, $\sigma_{p}$ is standard deviation of daily amounts of precipitation, and $p$ is the mean percentage of days with precipitation in the population of precipitation.

\section{Selection of key days}

There are many indices of solar activity. First, intense solar flares are used for selecting the key days. Here intense solar flare is defined by flares of importance 3 .

The solar flare indices which were calculated by Sekihara (1963), are used for selecting the key days. These indices are calculated by the following formula,

$$
I=\sum i t
$$

where $t$ is the time duration of solar flare expressed in minute and $i$ a weighting coefficient of $1.5,2.5$ and 3.5 corresponding to the magnitude of solar flares 1,2 and 3. Intense and weak solar flare indices are defined by the following criterion respectively.

$$
\begin{aligned}
& \text { Intense solar flare index } \geqq 1800 \\
& \text { Week solar flare index } \leqq 50
\end{aligned}
$$

The $K_{p}$ index, or index of geomagnetic disturbances and intensity of corpuscular flow, is next used for selecting the key days. Daily values of the $K_{p}$-index are available after 1937. Geomagnetically disturbed days and quiet days are selected by the following criteria.

Disturbed days $-K_{p}$ is greater than 40 and maximum

Quiet days $-K_{p}$ is smaller than 3 and minimum

Geomagnetically disturbed days and quiet days during 1924-1936 are selected subjectively by using the indices of geomagnetic disturbances observed at Kakioka geomagnetic observatory. This selection is rather arbi- 
trary, but it allows for less difficulty in selecting key days because there is a close correlation between $K_{p}$-index and geomagnetic disturbances at Kakioka. The latter days are important for our analysis because the amount of daily precipitation over China and the Pacific Ocean is only available before World War II.

\section{Time lag between solar flare and geo- magnetic disturbance}

It is well known that strong solar corpuscular flow penetrates into the upper atmosphere and geomagnetic disturbances occur a few days after the intense solar flares. For the purpose of fixing the time lag between these two phenomena analysis is made by taking days with intense solar flare and geomagnetically disturbed days as key days respectively.

Fig. 1 shows the results of key day analysis applied to $K_{p}$-index by taking the day with intense solar flare index and intense solar flares as key day respectively. It is clear that geomagnetic disturbances occur 2 or 3 days after the key day. The correlation is especially clear for the solar flare index. Fig. 2 shows opposite relationship. Curve a shows the change of number of days with strong solar flare index and $b$ shows the change of number of days with intense solar flare taking the key day to be the geomagnetically disturbed day. This shows that strong solar

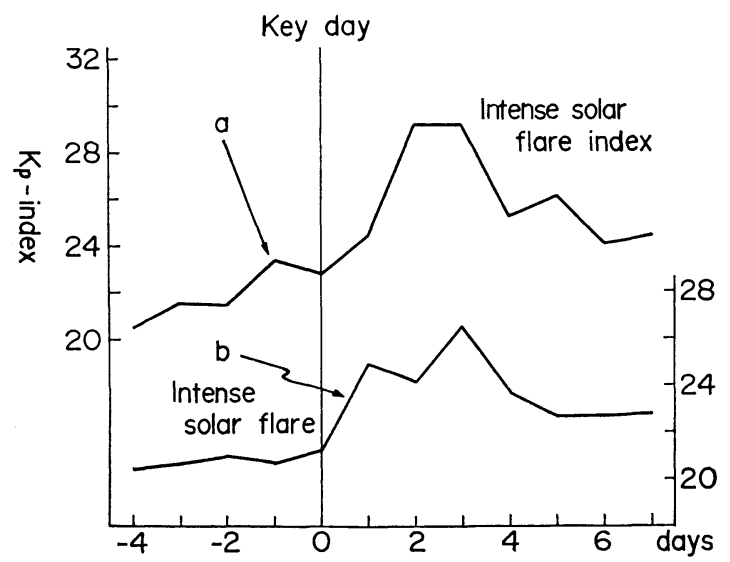

Fig. 1. Key day analysis of $K_{p}$-index around the day with intense solar flare.

a. sample size 37,1957 Jul. -1960

b. sample size $56,1957-1963$ flare occurs 3 days before the geomagnetically disturbed days. This relationship is clearer for the strong solar flare index than for the intense solar flare.

We can conclude from this analysis that the time lag between a solar flare and a geomagnetic disturbance or penetration of corpuscular flow is about 2-3 days.

\section{Intense solar flare and daily precipitation}

Key day analysis is applied to the daily amount of precipitation and heavy rain (more than $10 \mathrm{~mm}$ a day) at Asahikawa, Tokyo, Hachijojima, Kyoto and Kagoshima taking days with intense solar flare as key day. Location of stations is shown in Fig. 9. Fig. 3 and Fig. 4 show the change of mean amount of precipitation and number of days with heavy rain. The dotted lines parallel to the time axis show the range of standard errors.

Similar analysis is also made taking days with intense and weak solar flare index as key days. Some of the analysed results are shown in Table 1 and in Fig. 5. In these Figures, the ordinate expresses the mean precipitation or number of days with heavy rain; the abscissa time length from the key day. Full line parallel to the time axis shows expected mean precipitation or number of days with heavy rain. The dotted line shows the range of standard error assuming no statistical relationship between solar flare and precipitation. The dotted curve is the result of the analysis which takes the key day to be associated with the weak solar flare index. Sample size and

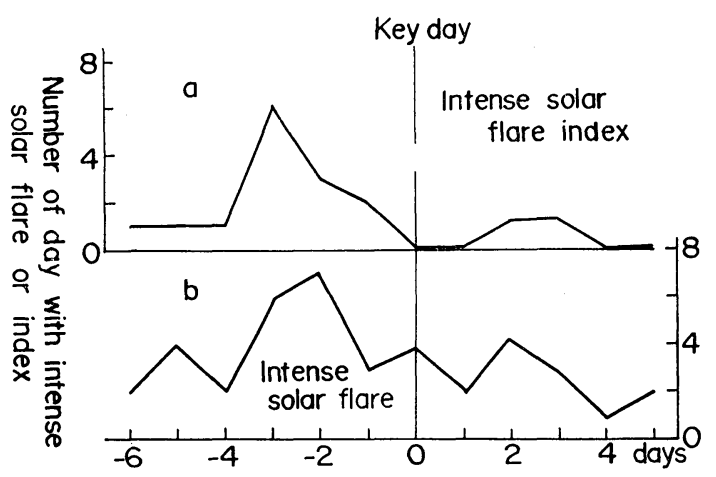

Fig. 2. Key day analysis of solar flare around geomagnetically disturbed day.

a. sample size 49,1957 Jun. -1960

b. sample size 31,1957 Jul. -1962 
Table 1. Key day analysis of daily amount of precipitation. $\varepsilon$ standard error, $N$ sample size, $\sigma_{p}$ standard deviation of daily amount of precipitation. (July 1957-December 1960)

Station

\section{Time} inter-

Key day with intense solar flare index

Torishima

Kagoshima

Hachijojima

Kyoto

Tokyo

Matsumoto

Wajima

Asahikawa

$\begin{array}{rll}4.2 & 4.6 & 1.1 \\ 6.6 & 4.8 & 8.3 \\ 12.3 & 3.8 & 8.5 \\ 9.9 & 5.8 & 3.8 \\ 3.9 & 1.8 & 2.3 \\ 4.4 & 1.7 & 3.9 \\ 11.8 & 6.4 & 8.6 \\ 3.3 & 4.2 & 2.8\end{array}$

2. 4

5. $7 \quad 4.5$

$\begin{array}{rrr}10.1 & 10.8 & 10.0\end{array}$

8. 9 9. 0 13. 3

2.2

5. 7

8. 7

$1.4 \quad 4.3$

6. 4

$5.5 \quad 14.1$

3. 6

4. 3

6. 7

3. 2

Key day with week solar flare index

\begin{tabular}{|c|c|c|c|c|c|c|c|c|c|c|c|c|c|c|c|c|}
\hline Torishima & 4.3 & 3.2 & 1.6 & 4.2 & 4. 0 & 2.7 & 5.4 & 3. 6 & 5.3 & 4. 7 & 6.3 & 7.8 & 4.4 & 1.6 & 54 & 12 \\
\hline Kagoshima & 4.3 & 7.1 & 6.2 & 3.9 & 7.0 & 4.2 & 3.9 & 4. 2 & 3.4 & 6.1 & 4.9 & 4. 7 & 6.4 & 1.8 & 54 & 13 \\
\hline Hachijojima & 8.2 & 6.7 & 6.4 & 9.8 & 6.8 & 10.1 & 8.6 & 11.7 & 9. 0 & 11.5 & 5.4 & 8.9 & 8. 3 & 2.2 & 54 & 16 \\
\hline Kyoto & 2.5 & 2.4 & 3. 3 & 4. 1 & 5.4 & 4.9 & 3.8 & 2.4 & 5. 0 & 4.7 & 1.7 & 2.6 & 4.3 & 1.5 & 54 & 11 \\
\hline Tokyo & 3.2 & 1.5 & 2.0 & 3.7 & 3.2 & 2.8 & 2.7 & 2.3 & 4.3 & 4. 6 & 5.4 & 1.0 & 4.3 & 1.6 & 54 & \\
\hline Matsumoto & 1.8 & 1.3 & 2.5 & 2.1 & 2.6 & 3. 1 & 3. 0 & 1.7 & 4.4 & 4.0 & 1.5 & 2.2 & 2.9 & 1.1 & 54 & \\
\hline Wajima & 5.9 & 6.3 & 9.1 & 7.5 & 8.4 & 9.5 & 11.7 & 6.8 & 9.4 & 9.1 & 4.1 & 7.1 & 6.2 & 2.9 & 54 & 21 \\
\hline Asahikawa & 2.6 & 4.9 & 4.6 & 1.9 & 3.6 & 3.6 & 4.5 & 2.6 & 2.6 & 2.7 & 2.4 & 2.1 & 3.1 & 1.1 & 54 & \\
\hline
\end{tabular}

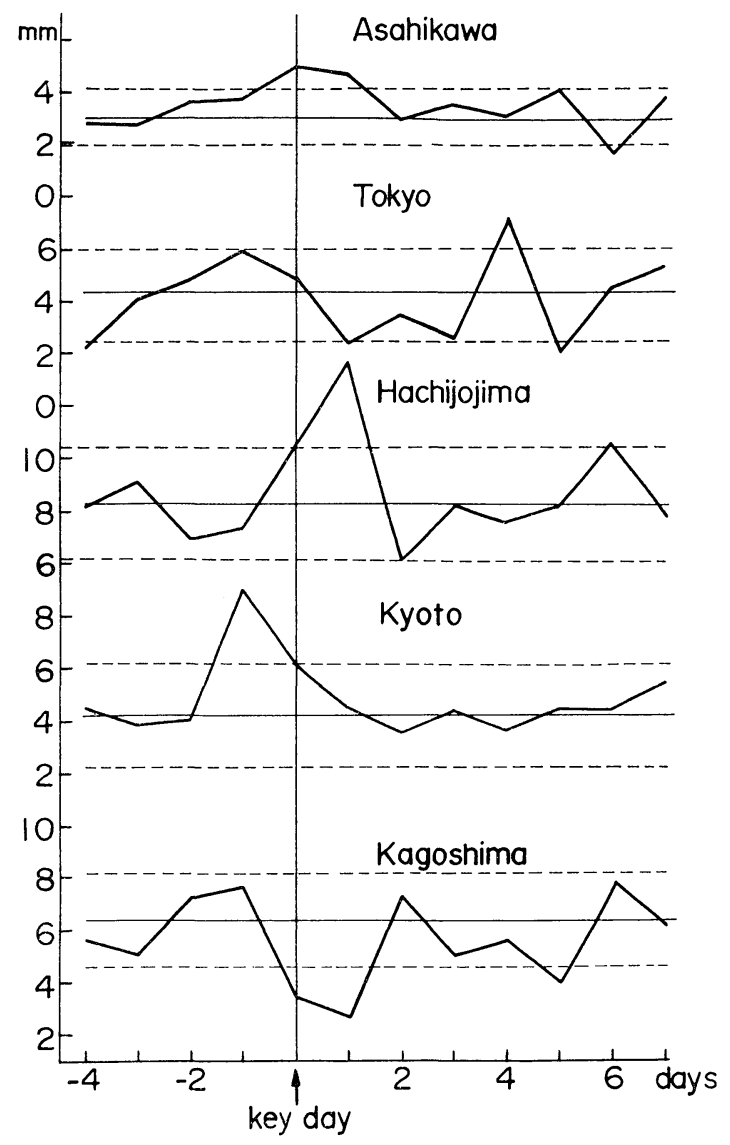

Fig. 3. Key day analysis of mean amount of precipitation.

Key day is day with intense solar flare. Sample size about 54. (1957-1963)

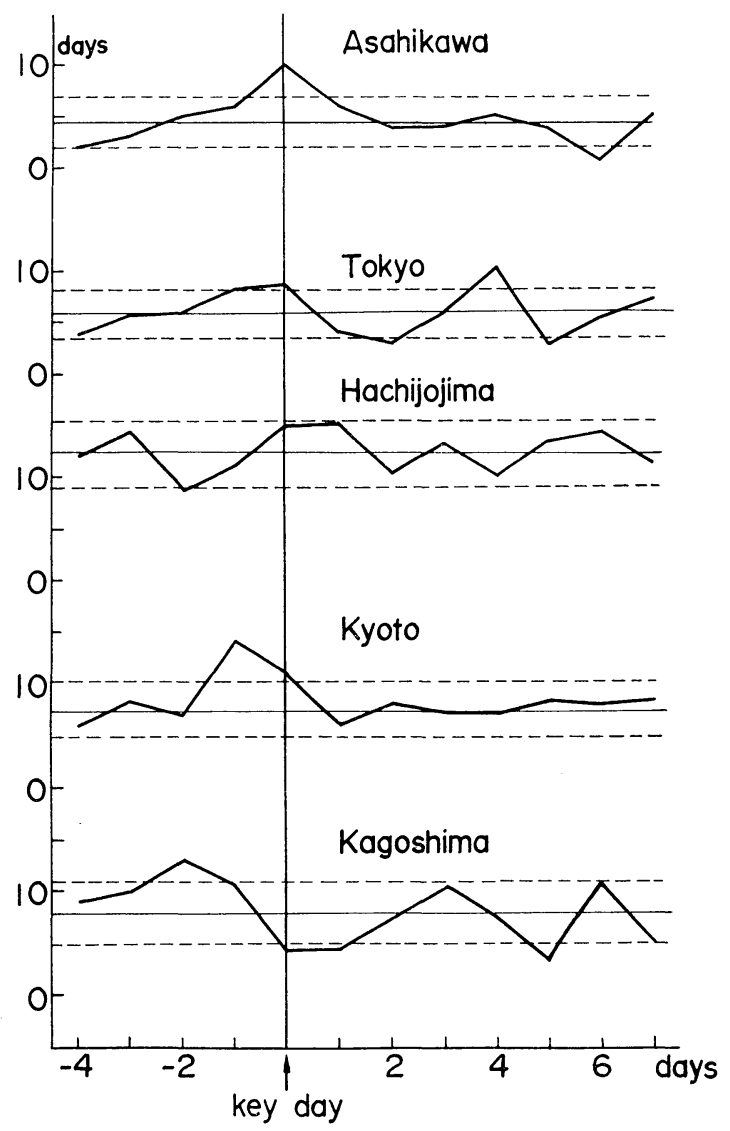

Fig. 4. Key day analysis of heavy rain. Key day is day with intense solar flare. 
the period of analysis is shown in Table 1.

Glancing at the Figures, we find distinct changes of precipitation on key days or one day before and also on 3 or 4 days later. This is especially clear in Fig. 5. For instance, the mean amount of precipitation on key day associated with intense solar flare at Asahikawa is $7 \mathrm{~mm}$ while expected amount is $3.1 \mathrm{~mm}$. The deviation is about 3 times the standard error. The mean amount of precipitation on 4 days after the key day at

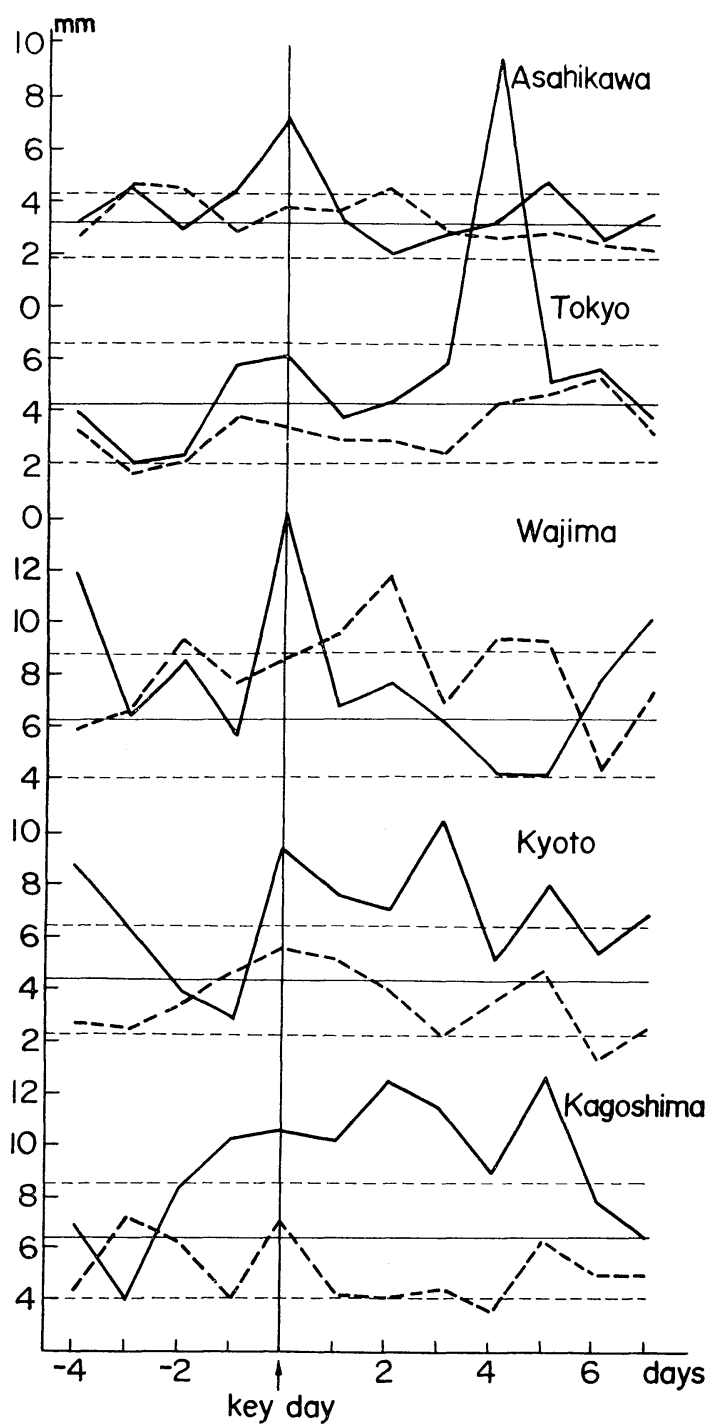

Fig. 5. Key day analysis of mean amount of precipitation.

Key day is day with strong and weak solar flare index.
Tokyo is $19 \mathrm{~mm}$. This is extraordinarily large compared with the expected value. The curve of the mean amount of precipitation at Kyoto shows an increase on key day and 3 days later. On the other hand, the dotted lines in Fig. 5, that is, the change of precipitation for key day with the weak solar flare index, show smaller variation than the full lines and most of them lie within range of the standard errors. These results confirm the above conclusion.

Though there are some differences at different stations, and some curves show small variations compared with the standard error (due to the randomness of the precipitation) we may conclude that precipitation increases on key day or one day before and 3 or 4 days after.

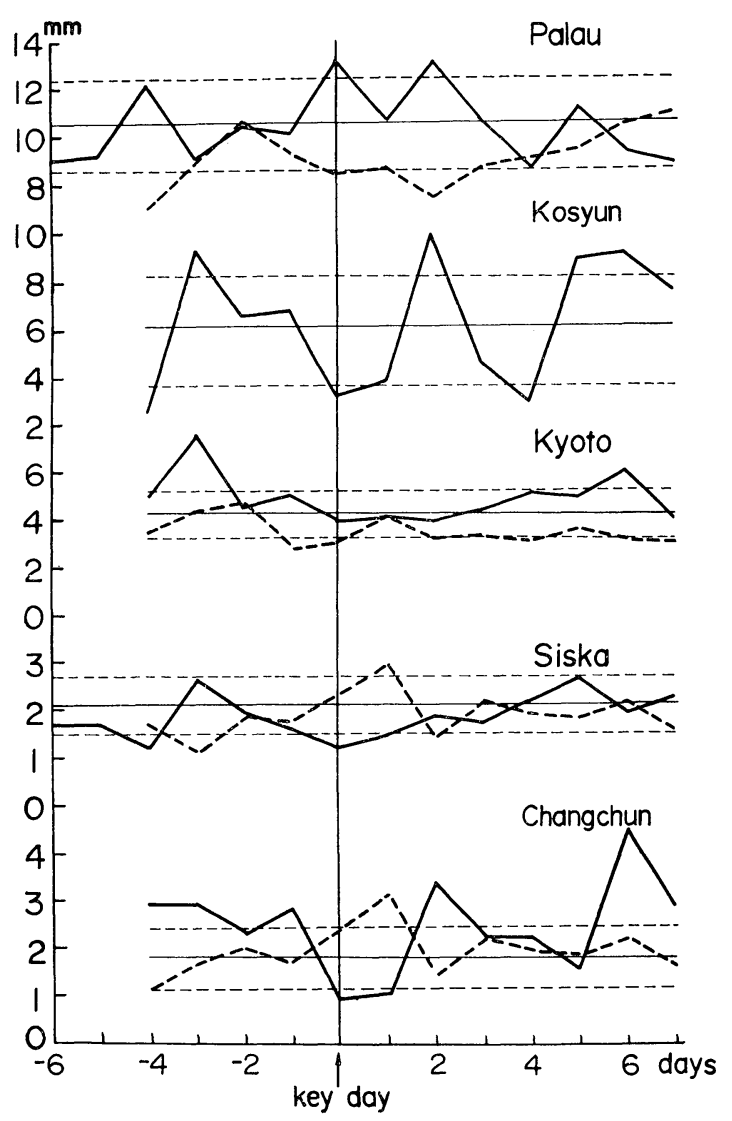

Fig. 6. Key day analysis of precipitation.

Full line-Key day with strong geomagnetic disturbances.

Dotted line-Key day with weak geomagnetic disturbances. 


\section{Geomagnetic disturbances and precipita- tion}

Next, using geomagnetically disturbed and quiet days as key days, similar analysis of precipitation at certain stations in the Far East is made. Some of the results are shown in Table 2. Here, expected values are calculated from the climatological table, $\varepsilon$ is standard error of the mean amount of precipitation calculated from $\sigma_{p}$ and $N$, assuming the data to be distributed in random samples. $\sigma_{p}$ is standard deviation of the daily amount of precipitation, $N$ is the sample size. Typical change in the mean precipitation vs. time distance from the key day are shown in Fig. 6. The full lines and dotted lines correspond to the curve for geomagnetically disturbed and quiet days respectively. The dotted lines parallel to the time axis show the range of the standard errors.

Though the amplitude of the curves is not as large as that for the solar flare (Fig. 3), the curve of Kyoto shows distinct increase of precipitation 3 days before the key day. This is statistically significant with a percentage of risk of but 0.02. Here the key day is the day with strong geomagnetic disturbances. This character is in good accordance with the increase of precipitation on the day with intense solar flare, just as we have found in the former section, because on the average the geomagnetically disturbed day occurs 3 days after intense solar flare. Such an increase is also found in the curve of the other stations though the statistical significance is not large.

An increase of precipitation is also found several days after the key day. For instance, distinct increase of precipitation is found 6 days after the key day at Kyoto, Nagasaki, Tokyo and Changchun. Generally speaking, the amount of precipitation decreases on the key day though the statistical significance is

Table 2. Key day analysis of mean amount of precipitation at some stations in Far East.

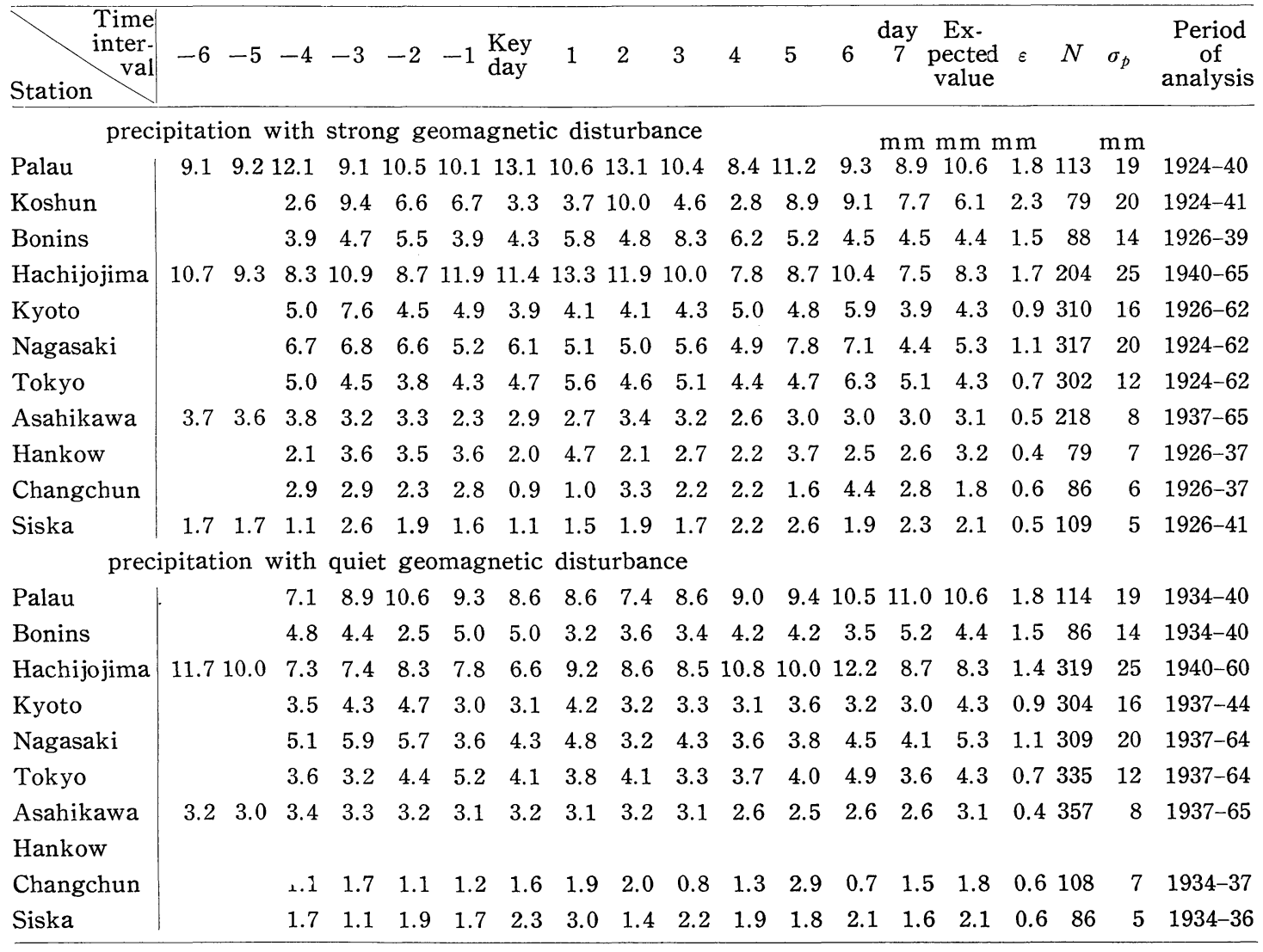


not large. Such a conclusion is confirmed by an opposite tendency of the dotted lines, that is, the time change of the precipitation for quiet $K_{p}$-index, to the full lines in Fig. 6 and Fig. 7.

The mode of such a response of the mean precipitation, however, depends on location and season. The curve at Palau over the equatorial region, shows changes a day earlier than the other stations while some stations show increase of precipitation 1 or 2 days after the key day.

Table 3 and Fig. 7 portrays the results of key day analysis applied to the mean precipitation at 3 stations in Japan, (Nagasaki, Kyoto and Tokyo) during 4 seasons of the year. Here the seasons are defined as follows

Winter-December to February

Spring-March to May

Summer-June to August

Autumn-September to November

Glancing at Fig. 7, we find that the winter curve shows an increase of precipitation 1 or 2 days before and 3 or 4 days after the key day. The spring curve shows an increase of precipitation at the key day and 4 days after. The summer curve shows rather irregular changes. The autumn curve shows an increase of precipitation 3 days before and 6 days after the key day. We also find that the winter curve resembles that of Changchun, the source region of the continental air masses. The spring curve resembles that of Palau, source region of the maritime air masses, and the autumn curve with the general response curve of precipitation amount for the geomagnetic disturbance.

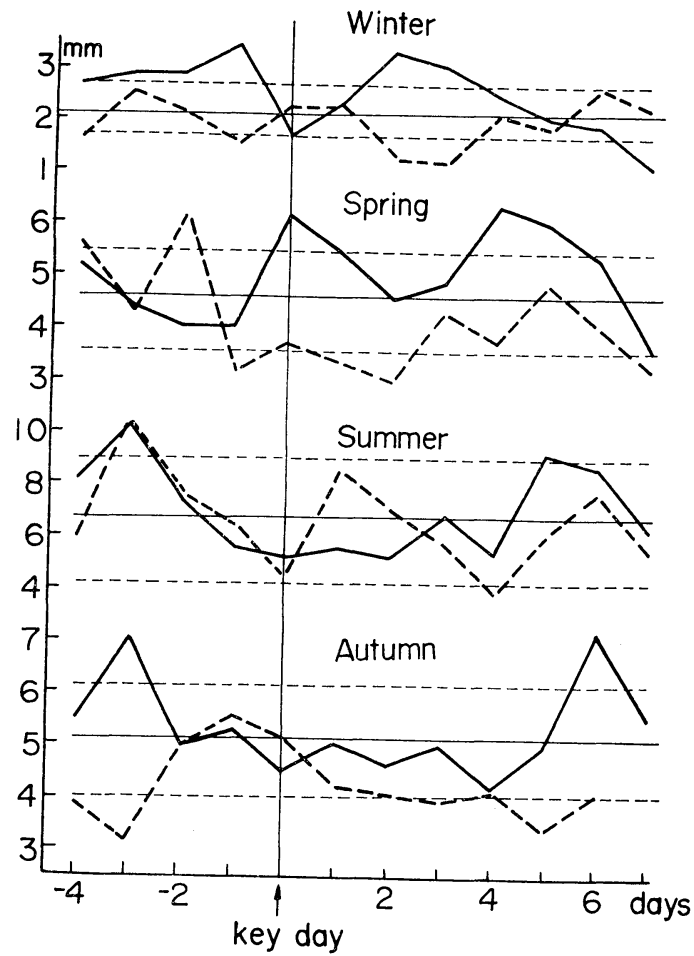

Fig. 7. Key day analysis of mean precipitation at Nagasaki, Kyoto and Tokyo. (1926-1962)

Full line-Key day with strong geomagnetic disturbances.

Dottled line-Key day with weak geomanetic disturbances.

Table 3. Key day analysis of mean precipitation at Nagasaki, Kyoto and Tokyo.

$\varepsilon$ standard error, $\sigma_{p}$ standard deviation of daily amount of precipitation, $N$ sample size. (1926-62)

\begin{tabular}{|c|c|c|c|c|c|c|c|c|c|c|c|c|c|c|c|c|}
\hline \multicolumn{12}{|c|}{ precipitation with large geomagnetic disturbances } & \multirow{2}{*}{$\begin{array}{c}\mathrm{mm} \\
1.1\end{array}$} & \multirow{2}{*}{$\begin{array}{c}\mathrm{m} \mathrm{m} \\
2.2\end{array}$} & \multirow{2}{*}{$\begin{array}{c}\mathrm{mm} \\
0.5\end{array}$} & \multirow{2}{*}{\multicolumn{2}{|c|}{$125 \underset{5}{\mathrm{~mm}}$}} \\
\hline Winter & 2.7 & 2.9 & 2.9 & 3.4 & 1.7 & 2.3 & 3.3 & 3. 0 & 2.4 & 2. 0 & 1.9 & & & & & \\
\hline Spring & 5.2 & 4. 4 & 4. 0 & 4. 1 & 6. 2 & 5.5 & 4.5 & 4.9 & 6.4 & 6. 0 & 5.3 & 3.5 & 4. 6 & 0.9 & 311 & 15 \\
\hline Summer & 8.1 & 10.1 & 7.2 & 5.5 & 5.3 & 5.6 & 5.2 & 6.7 & 5.3 & 9.1 & 8.6 & 6.1 & 6.7 & 2.3 & 216 & 34 \\
\hline Autumn & 5.5 & 7.0 & 5.0 & 5.3 & 4. 5 & 5.0 & 4.6 & 4.9 & 4. 0 & 4. 9 & 7.1 & 5.5 & 5.1 & 1.1 & 292 & 18 \\
\hline \multicolumn{17}{|c|}{ precipitation with small geomagnetic disturbances } \\
\hline Winter & 1.7 & 2.6 & 2.2 & 1.5 & 2.2 & 2.3 & 1.3 & 1.2 & 2.1 & 1.8 & 2.6 & 2.2 & 2.2 & 0.4 & 281 & 6 \\
\hline Spring & 5. 6 & 4. 3 & 6.2 & 3.1 & 3. 7 & 3.3 & 3. 0 & 4.3 & 3.8 & 4.8 & 4.1 & 3.1 & 4.6 & 1.0 & 208 & 15 \\
\hline Summer & 5.9 & 10.3 & 7.5 & 6.4 & 4.7 & 8.5 & 6.7 & 5.8 & 3.8 & 6.2 & 7.6 & 5.4 & 6.7 & 2.5 & 180 & 34 \\
\hline Autumn & 3.8 & 3.1 & 5.0 & 5.5 & 5.0 & 4. 2 & 4.0 & 3.9 & 4. 2 & 3. 4 & 4.0 & 4. 0 & 5.1 & 1.1 & 278 & 18 \\
\hline
\end{tabular}




\section{Discussion and conclusion}

From the present analysis we can conclude with little statistical risk that precipitation is stimulated on a day with intense solar flare. This suggests that soft $X$ ray or very fast corpuscular flow, probably cosmic ray emmitted from the solar flare, stimulates the precipitation. Though there is serious diffculty in the above explanation that soft $\mathrm{X}$ ray and corpuscular flow are absorbed in the upper air above $60 \mathrm{~km}$ and that they may not reach into the troposphere, small increases of cosmic ray accompanied by solar flare has been shown by S. Yoshida (1965) and others. The possibility remains for such an explanation. The present results may help in understanding the physical process between solar activity and meteorological phenomena. An increase of precipitation is associated on the same day with an intense solar flare.

Distinct decrease of precipitation is found in many stations on geomagnetically disturbed days, that is, about 2 or 3 days after the intense solar flare. This is natural, because there may be a slight change of the evaporation rate of water from the earth's surface, and a decrease of the precipitation must follow after the distinct increase of precipitation.

Increase of precipitation are also found at some stations on a day with strong geomagnetic disturbances and 6 days after. The mode of these secondary increases depends on the seasons and stations and they are not so distinct as the increase on the days with intense solar flare. Accordingly, these increases of precipitation may be due to indirectly produced circulation which result from the initial increase of precipitation.

Summarizing the changes of precipitation,

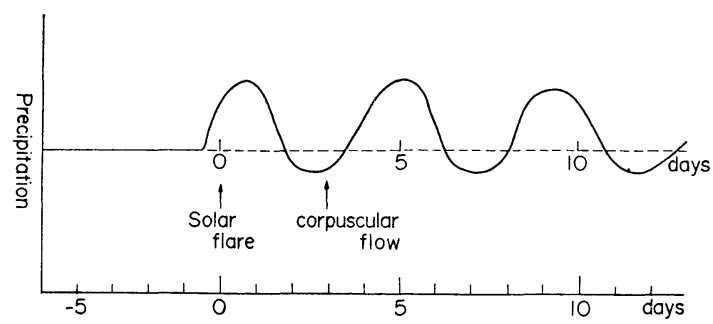

Fig. 8. Model of response of precipitation to intense solar flare.

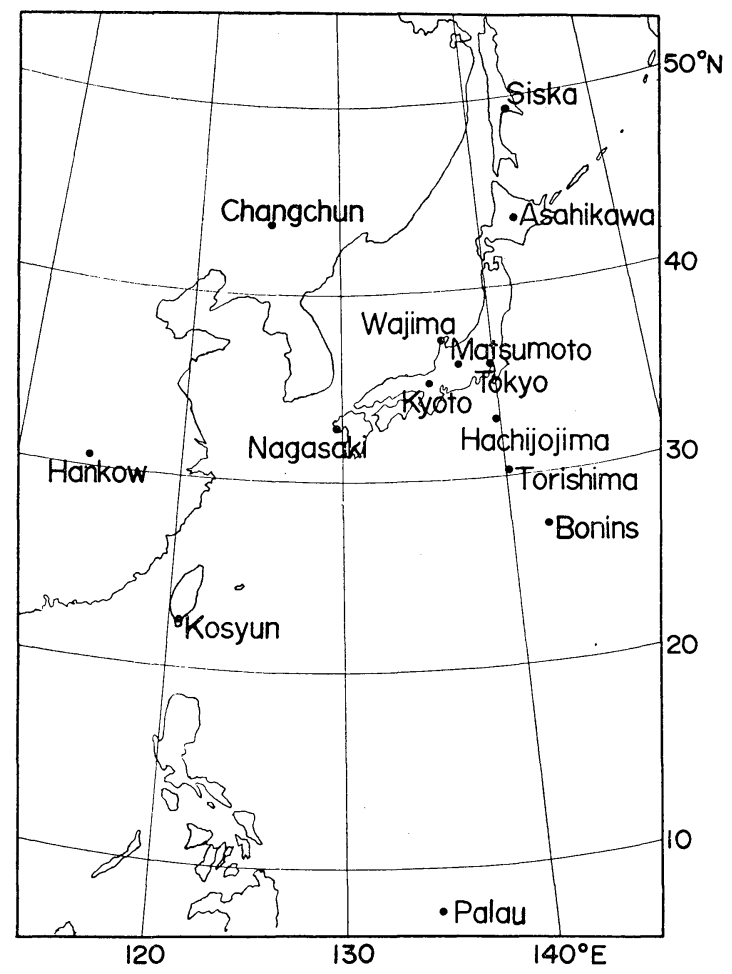

Fig. 9. Location of the stations.

a model of a responces of precipitation to intense solar flare has been made and is shown in Fig. 8. Firstly intense solar flares stimulate the precipitation, and then secondary increases of precipitation follow due to the indirectly produced circulations due to the initial increase of precipitation.

Of course, there are many ambiguities in this conclusion and the present analysis is made only on precipitation in the Far East. The author hopes that some one in another part of the world will check the present results.

\section{Acknowledgments}

The author wishes to express his sincere thanks to Dr. M. Komabayasi and Mr. T. Suda for their valuable comments and discussions and to Dr. W. M. Gray for his advice and correcting the manuscript, and to Miss J. Hashiba, Miss Y. Sasaki, Miss M. Sasaki and Mrs. N. Kiyomi who carried out the calculations and to Mrs. Y. Tsuneoka who traced the graphs and typed the manuscript. 


\section{References}

Asakura, T. and A. Katayama, 1958: On the relation between solar activity and general circulation in the atmosphere. Papers in Meteor. and Geophys., 9, 15-24.

Craig, R. A., 1952: Surface pressure variations following geomagnetically disturbed and geomagnetically quiet days. J. Meteor., 9, 126-138.

Duell, B. and G. Duell, 1948: The behavior of barometric pressure during and after solar possible invations. Smith. Miss. Coll. 110, 8, 1-31.

Roberts, W. O., 1956: Cross-field seminar on possible responses of terrestrial atmospheric condition to change in solar activity. Bull. Amer. Meteor. Soc., 37, 477-479.

1965: Weather and cosmic influences.
Bull. Amer. Meteor. Soc., 46, 196-197.

Sekihara, K., 1963: Study on solar activity and atmospheric ozone. Papers in Meteor. and Geophys., 14, 34-52.

Shapiro, R., 1956: Further evidence of a solar weather effect. J. Meteor. 13, 335-340.

Trenkle, H., 1957: The zonal wind component in the Atlantic-European sector as influenced by short scale fluctuation in solar activity. Scien. Rep., No. 2, 1-14.

Woodbridge, D. O., J. W. Pohrte and N. Macdonald, 1957: A possible effect in $300 \mathrm{mb}$ circulation related to solar corpuscular emission. Tech. Rep., 3, Solar Terrestrial Research, High Altitude Observatory.

Yoshida, S., 1965: Solar cosmic Rays associated with meter type IV radio burst. J. geophys. Res., 70, 2065-2075.

\title{
太陽活動の変動と日降水量との関係のキイ・デイ解析
}

\author{
高 橋 浩 一 郎
}

気象研究所

太陽活動の変動と気象との関係を明らかとする目的で太陽活動の示数となる地磁気の变動度やソーラー・フレャー を示数にとり，極東各地の日降水量との関係をキー・デイ解析によって調べた。

この結果によると, 統計的には顕著なリーラー・フレヤーのあった日に日降水量は增加する傾向がはっきりしてい る。従来太陽からくる微粒子流が注目されているが，この結果からみるとソーラー・フレヤーにとあなって増加する 軟X線，または宇宙線などが何らかの機棈とより降水量を增加させるようと働くとみた方がよいようである。

多くの地点では地磁気の変動度の大きい日には，むしろ日降水量は減るところが多い。これは，地磁気の変動は顕 著なソーラー・フレヤーの起きた時より 2,3 日遅れて大きくなるので, 顕著なソーラー・フレヤーの起きた日に大 気中の水が降水となって落ちてしまうとすれば説明がつく。

な拈，ところとよっては鍵の日より 2 日目とか 6 日目頃飞 2 次，3 次の降水量の增加が認められるが，これは持 らくソーラー・フレヤーによって生じた降水により，2 次， 3 次の循環が生じ，降水が增すためであろろ。

な怙, 本研究の経費の一部として「異常気象の綜合的研究」に対する文部省の科学研究費の援助をえたので, 感謝 の意を表する。 